JOURNAL OF

RESEARCH

AND

REVIEW

IN SCIENCE

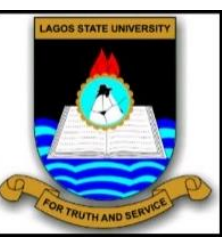

\title{
Assessment of Liquefaction Potential of some Coastal Soils in Lagos, South- Western Nigeria Using Geophysical and Geotechnical Methods
}

\author{
Hamid Oladunjoye ${ }^{1}$, Kayode Oyedele ${ }^{2}$, Lukumon Adeoti ${ }^{2}$, Kehinde S. Ishola ${ }^{2}$
}

${ }^{1}$ Department of Physics, Faculty of Science, Olabisi Onabanjo University, Ago-Iwoye, Nigeria

${ }^{2}$ Department of Geosciences, Faculty of Science, University of Lagos, Akoka, Nigeria

\section{Correspondence}

Hamid Oladunjoye, Department of Physics, Faculty of Science, Olabisi Onabanjo University, Ago-Iwoye, Nigeria

Email:oladunjoye.hamid@gmail.com

\begin{abstract}
:
Introduction: Liquefaction occurs in shallow, loose, saturated deposits of cohesionless soils subjected to strong shearing stresses. This leads to the transfer of stress from the soil skeleton to the pore water precipitating a decrease in effective stress and

shear resistance of the soil. The study gives the results of the liquefaction potential assessment in some parts of Lagos wetland areas of Lagos.

Aim: The aim of this study was to assess the liquefaction potential through the evaluation of its severity in response to Earth tremors. Materials and Methods: In order to achieve this purpose, Multi-channel Analysis of Surface waves (MASW) and Cone penetration testing (CPT) were carried out. For an optimal coverage of the study area, twenty-four channels $4.5 \mathrm{~Hz}$ geophones connected to the ABEM Mark 6 Seismograph through two cable reels were used to detect the generated seismic wave produced by the weight drop of about $19.1 \mathrm{~kg}$. The CPT soundings for assessing subsurface stratigraphy with respect to liquefiable soils were carried out with a 10-Ton Dutch Cone Penetrometer. The softwares used were Seislmager, for processing the MASW data and CLiq for the CPT measurements.

Results: The shear wave velocity models were generated for the MASW measurements. The models show that sand sediments with velocity ranging from $118-279 \mathrm{~m} / \mathrm{s}$ dominated most of the study area. Also, the results show that for the potential liquefiable sands delineated at depths between $10.0-20.0 \mathrm{~m}$, the shear wave velocity ranges between $118.0-$ $180 \mathrm{~m} / \mathrm{s}$. The results of the CPT show that the soil behavior type index is between $1.70-2.50$. This suggests that the soils in the study area are susceptible to cyclic liquefaction with normalized friction ratio less than 1. Conclusion: The study showed the presence of loose sand sediments in some Coastal soils of the study area. This cohesionless soil are susceptible to agitation and liquefaction in the presence of strong Earth shaken.
\end{abstract}

Keywords: Liquefaction, Soil, Wetland, CPT, MASW, Geophones, Sand 


\section{INTRODUCTION}

Liquefaction phenomenon is among geological hazards that occur as a result of increased monotonic or cyclic shear loads or shock loading. It leads to loss of strength/stiffness of saturated or partially saturated cohesionless soil which makes it to lose its bearing capacity as it behaves like liquid. The solid state of soil is transformed into liquefied state in response to increased pore pressure and reduced effective stress. Liquefaction occurs when there is decrease in soil volume as a result of shearing stresses. When loose, partially/saturated soils are subjected to shearing, there is a re-arrangement in the soil grains to a kind of dense packing devoid of much space as a result of forceful ejection of water in the pore spaces [1]. This phenomenon occurred through the application of shear stress via the reduction in the inter-particular contact of the sand granule sand leading to the build-up of the interstitial pore water pressure [2]. This action leads to decrease in effective stress and shear resistance as the stress from the soil skeleton has been transferred to the precipitating pore water. When the shear resistance has reduces compared to static or driving shear stress, the soil will be seen undergoing a large deformation in form of Liquefaction.

The adverse effects of liquefaction include flow due to failure of slopes, settling and tipping of buildings and collapse of retaining walls. Recent studies have identified geologic deposits and sandy soils to be most susceptible to liquefaction. Also, saturated granular soils without cohesive fines (i.e., some silts, sands, and gravels) are most susceptible to the buildup of pore pressure. Shear stress or shock loading involved in liquefaction phenomenon can be inform of uneven forces, sudden change in stress condition earth tremors or earthquakes. Most of the cases of liquefaction studied so far were after the ground shaken forces like earthquakes [3, 4]. Simplified procedure for the assessment of liquefaction was based on ground shaken like earthquake.

Nigeria is not part of the countries that are prone to Seismogenic activities such as: earthquakes and volcanoes. This is because its location is very far from the active plate tectonics. Likewise it is not situated at the boundary/edge of the plate where the shearing process of the plates can induce the seismic activity. An earthquake usually occurs along tectonic plate boundaries (inter-plate) or occasionally outside the plate margins (intra-plate) in a shearing form [5]. Several seismic activities have been recorded in Nigeria in form of Earth tremors. These occurrences have been dated back to Earth tremors experienced in 1933 and 1939 in Warri and Lagos respectively, which make Nigeria not to be immune to earthquake as previously believed $[4,5,6]$. About twenty-Eight cases (28) of earth tremors occurrences have been recorded in Nigeria [7] as shown in (Table 1).
Table 1: Earth Tremors in Nigeria. (Modified after [5, 6])

\begin{tabular}{|c|c|c|}
\hline $\mathbf{S} / \mathbf{N}$ & DATE & TOWN \\
\hline 1 & 1933 & WARRI \\
\hline 2 & JUNE 1939 & LAGOS \\
\hline 3 & JULY 1948 & IBADAN \\
\hline 4 & JULY 1961 & OHAFIA \\
\hline 5 & DECEMBER 1963 & IJEBU-ODE \\
\hline 6 & APRIL 1981 & KUNDUM \\
\hline 7 & OCTOBER 1982 & JALINGO \\
\hline 8 & JULY 1984 & IJEBU-ODE/ SAGAMU \\
\hline 9 & DECEMBER 1984 & YOLA \\
\hline 10 & JUNE 1985 & KOMBANI YAYA \\
\hline 11 & JULY 1986 & $\mathrm{OBI}$ \\
\hline 12 & JANUARY 1987 & GEMBU \\
\hline 13 & MARCH 1987 & AKKO \\
\hline 14 & MAY 1987 & KURBA \\
\hline 15 & MAY 1988 & LAGOS \\
\hline 16 & JUNE 1990 & IBADAN \\
\hline 17 & $\begin{array}{l}\text { NOVEMBER } \\
1994\end{array}$ & IJEBU ODE \\
\hline 18 & JUNE 1997 & OKITIPUPA \\
\hline 19 & MARCH 2000 & BENIN \\
\hline 20 & MARCH 2000 & IBADAN/ABEOKUTA \\
\hline 21 & MAY 2001 & LAGOS \\
\hline 22 & AUGUST 2002 & LAGOS \\
\hline 23 & MARCH 2005 & YOLA \\
\hline 24 & MARCH 2006 & LUPMA \\
\hline 25 & JUNE 2016 & KADUNA \\
\hline 26 & JUNE 2016 & KADUNA \\
\hline 27 & JULY 2016 & BAYELSA \\
\hline 28 & AUGUST 2016 & SAKI \\
\hline
\end{tabular}

Most of these tremors have intensity levels ranging from IV to VI with magnitude varying from 3.7 to 4.5 [8]. Several authors have attributed these occurrences to a fault that cut across the Precambrian Basement Complex of Nigeria called Ifewara-Zungeru fault. The fault zone shows a linkage with the Atlantic fracture system. Future occurrences of Earth tremors have been predicted to be along this fault which covers the coastal area of Lagos [9, 10]. This recurring menace has proven that Nigeria is not totally free from seismic activities. These unexpected activities require urgent study of the aftermath of seismic activity like liquefaction, tsunami, etc.

The three basic factors for liquefaction potential are the (i) presence of loose sands (ii) degree of saturation (iii) presence/occurrence of seismic shock loading. Several methods have been proposed in respect to the study of liquefaction potentials. Most of the current methods for assessing soil liquefaction potentials are based on either the standard penetration test (SPT) $[11,12]$ or the cone penetration test (CPT) $[13,14]$. In recent times, geophysical prospecting using surface wave techniques has gained rapt attention for the 
investigation of subsurface soils $[15,16]$. To this end, this paper focuses on the assessment of soil liquefaction potential conducted in some parts of Lagos wetland using integrated approach.

\subsection{GEOLOGIC SETTINGS}

Lagos wetland belongs to the coastal plain sand formation which is made up of loose sediment ranging from silt, clay and fine to coarse grain sand [17]. It is within the Dahomey Basin which is the combination of inland, offshore and coastal sedimentary basin in the Gulf of Guinea extending from southeastern Ghana in the west to the western flank of the Niger Delta [18, 19]. The Basin is bounded in the west by faults and other tectonic structures associated with the landward extension of the fracture zone. Its eastern limit is similarly marked by the Hinge line, a major fault structure marking the western limit of Niger Delta [20]. It is also bounded in the north by the Precambrian basement rock and the Bright of Benin in the south.

The sequential arrangements of rock unit within the study from the top are the Coastal Plain Sands, Ilaro Formation, Oshosun Formation, Akimbo Formation, Ewekoro Formation, and Abeokuta Formation lying on the Southwestern Basement Complex of Nigeria [19]. The Ewekoro Formation, which conformably overlies the Abeokuta Formation is Palaeocene in age and consists of limestone, shale and clay members. The llaro Formation overlies the Ewekoro Formation and is of Eocene age. The Coastal Plains Sands unconformably overly the llaro Formation and is Pleistocene to Oligocene in age. The lithology consists essentially of sands, silts and clay deposits with traces of peat in parts. The sediments range in size from coarse to medium grained, clean, white, loose sandy soil. Litho-stratigraphic information from boreholes in around the Lagos wetland reveals that typical section of the stratigraphy consists of unconsolidated dry and wet sand, with organic clay deposits. The deposits are sometimes interbeded in places with sandy clay or clayey-sand and mud with occasional varying proportion of vegetable remains and peat.

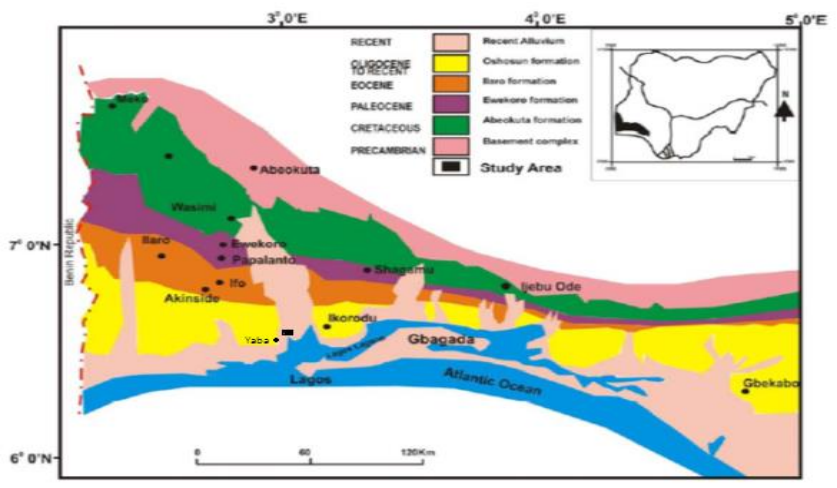

Figure 1: Geologic Map of Eastern Dahomey Basin [17]

\section{MATERIAL AND METHODS}

\subsection{Basic Concepts}

Soil liquefaction potential can be evaluated through the following parameters as related to geotechnical and geophysical studies.

\subsubsection{Cone Penetration Tests (CPT)}

CPT gives continuous profile of penetration resistance through the stratigraphic interpretation. Detailed information of soil layers is obtained from this test. CPT soundings give more reliable assessment of liquefaction potential compare to other penetration tests [21, 22]. Liquefaction potential assessment was carried from the acquired CPT data using Simplified Procedure for the evaluation of Liquefaction resistance [23]

The Cyclic Stress Ratio (CRR) can be expressed as; [12]

$C R R=\exp \left\{\frac{q_{c 1 N}}{540}+\left(\frac{q_{c 1 N}}{67}\right)^{2}+\left(\frac{q_{c 1 N}}{80}\right)^{3}+\left(\frac{q_{c 1 N}}{114}\right)^{4}-3\right\}(1)$

$q_{c 1 N}$ is the normalized cone tip resistance

$q_{c 1 N}=C_{Q}\left(\frac{q_{c}}{P_{a}}\right)$

If;

$C_{Q}=\left(\rho_{a} / \sigma_{v 0}^{\prime}\right)^{n}$

where:

$\mathrm{C}_{\mathrm{Q}}$ is the normalizing factor for cone penetration resistance

$P_{a}$ is equivalent to $1 \mathrm{~atm}$ of pressure

$\sigma_{v 0}^{\prime}$ is the effective vertical overbudden stress

$q_{c}$ is the field cone tip resistance

$\mathrm{n}$ is the exponent that varies with soil type, it is function of grain characteristics of the soil [24] the value is between 0.5 to 1.0. Soil - behaviour Type Chart proposed by Robertson [21] was used in determining the liquefaction assessment parameters such as Friction ration $(F)$ and soil type Index (Ic) 


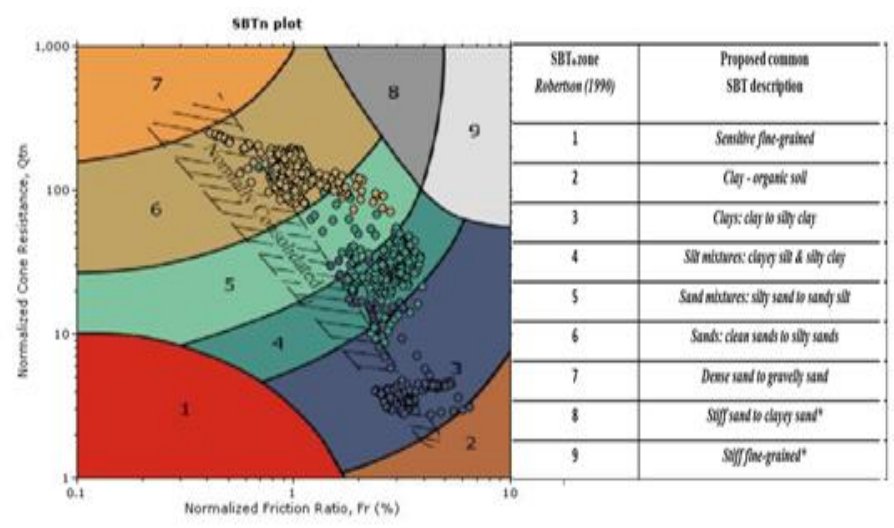

Figure 2: Soil behavior -Type Chart [21]

The soil behaviour type index $\left(I_{c}\right)$ termed as the radius of concentric circles is expressed as:

$$
I_{c}=\left\{(3.47-\log Q)^{2}+(1.22+\log F)^{2}\right\}^{0.5}
$$

where:

$Q=\left[\frac{q_{c}-\sigma_{v 0}}{\rho_{a}}\right] C_{Q}$

$F=\left[\frac{f s}{q_{c}-\sigma_{v 0}}\right] \times 100 \%$

Friction ratio is a function of degree of fines and soil plasticity. The above chart allows the rough estimate of soil type and fines content from the CPT data.

\subsubsection{Cyclic Stress Ratio (CSR)}

CSR is the seismic demand on a soil layer due for liquefaction. It is the average cyclic shear stress generated by earthquake before liquefaction. It can be expressed as:

$C S R=\frac{\tau_{a v}}{\sigma_{v 0}^{\prime}}=0.65 \frac{a_{\max }}{g} \cdot \frac{\sigma_{v 0}}{\sigma_{v 0}^{\prime}} r_{d}$

where:

$a_{\max }$ is the peak horizontal acceleration at the ground surface

$\sigma_{v 0}$ is the total vertical overbudden stress

$\sigma_{v 0}^{\prime}$ is the effective vertical overbudden stress

$G$ is the acceleration due to gravity

$r_{d}$ is the stress reduction ratio/coefficient.

\subsubsection{Multi-Channel Analysis of Surface Waves (MASW)}

MASW is a fast method of evaluating near-surface shear wave velocity profile because the entire range of investigation depth is covered by one or a few generation of ground roll without changing receiver configuration. Furthermore, the inclusion of noise wave fields such as body waves (direct, refracted, reflected, and air waves) [26, 27] and reflected [28] and highermodes [29] ground roll can be identified by their different coherency in arrival times on a multi-channel record and can be handled properly by various kinds of multi-channel data processing techniques to improve the accuracy of the results from the analysis. Three steps are involved in a surface wave test and they include: (i) field testing for recording surface waves, (ii) generation of dispersion curve from the field data, and (iii) inversion of shear wave velocity profile from the dispersion curve. [30, 31]

$$
\begin{aligned}
& Z_{\text {max }} \approx 0.5 \lambda_{\text {max }} \\
& \lambda_{\text {max }} \approx L \\
& Z_{\text {max }} \approx 0.5 L \\
& Z_{\text {max }} \leq \mathrm{L} \leq 3 Z_{\text {max }}
\end{aligned}
$$

The receiver spacing $(\mathrm{dx})$ is related to the shortest wavelength that can be analyzed, thus determining the shallowest resolvable depth of investigation $\left(z_{\mathrm{min}}\right)$ (MASW, n.d.a.), i.e.

$d x=n \cdot Z_{\min }$

\subsection{Data Acquisition and Processing}

The field work presented in this paper involves both geotechnical and geophysical studies carried at three different locations (i.e., Ikoyi, Badore and Lekki) of the Lagos wetland. These areas were chosen because of their closeness to Lagos lagoon and Atlantic Ocean. Four geotechnical soundings were performed to carry out the CPT and SPT tests. The CPT sounding was carried out with the ten Tones (10 ton) cone penetrometer machine. The Cliq software was used to process the CPT sounding data collected. This gives the stratigraphic sequence, the liquefaction model curve and soil behaviour type.

A 24-channel ABEM Terraloc Mark 6 Seismograph was used to record the impacts of a fabricated $19.1 \mathrm{~kg}$ weight drop used as energy source for the MASW tests. The survey parameters used to ensure good signal strength and optimal coverage of the area under the seismic profiles established were recording time and sampling intervals set at $1 \mathrm{~s}$ and $0.5 \mathrm{~ms}$ respectively. The roll along method was used throughout the surveys. The dispersion curves and the inversion of the shear wave velocity profiles were obtained using the procedure described in the SeisImager/SW software manual.

\section{RESULTS AND DISCUSSION}

The result of the CPT soundings is presented in Figs. 3 and 4 . It shows the resistance of the ground to the load subjected to it from the surface as function of depth. Also, it shows the corresponding stratigraphic 
sequence delineated at different depths. At shallow depth less than $7.5 \mathrm{~m}$, the cone resistance is the range of $0-10 \mathrm{MPa}$. This low CPT value suggests that the soil encountered at this depth is silty sand, which is less cohesive. The cone resistance is however observed to increase gradually at depth between $9.5-$ $18 \mathrm{~m}$, Expect that, it is noted to be nearly steady at depth between $11.5-15.0 \mathrm{~m}$. The cone resistance values lie between $40-100 \mathrm{MPa}$ and correspond to sand sediments.
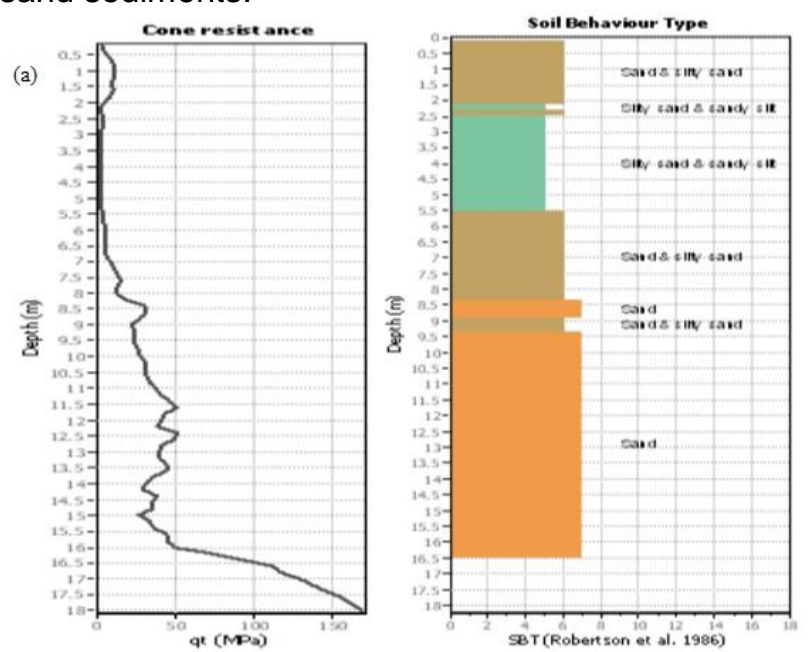

Figure 3: Typical cone resistance curve and corresponding soil types

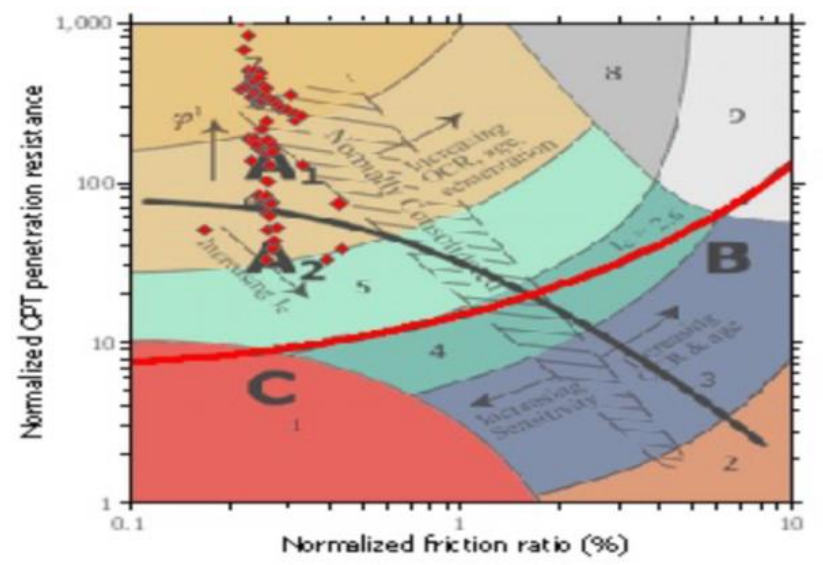

Figure 4: Soil Behavior Type Chart for the Study Area

The soil behavior type chart for the CPT soundings is presented in Fig. 4. It is noted that the soil in the investigated area is found to be mainly drained dilative soils. The concentricity in which they are found shows that the area is dominated by sand sediments with little fines, although, the presence of silty sands with little degree of fines is also observed in the latter concentric with little points. Also, the soil behavior type index falls between $1.70-2.5$. This means that the soil is susceptible to cyclic liquefaction. The normalized friction ratio obtained is less than 1 , confirming the degree of fines of the silty sand in the study area. The friction ratio which is a function of grain characteristics increases with increase in fine content and plasticity. This shows that the sand sediments in this area possess low plasticity index as depicted in the normalized friction ratio.
The liquefaction model curve (LMC) which provides the extent of liquefaction points obtained from a plot of CSR against normalized cone tip resistance (q_c1N) is shown in Fig. 5. The LMC differentiates the region prone to liquefaction from non-liquefaction region. The LMC is linked with the Factor of safety (FS) set at 1. The FS is estimated as ratio of Cyclic Resistance Ratio (CRR) to Cyclic Stress Ratio (CSR). The red color shows cluster of liquefiable points with FS less than 1 while the blue color indicates cluster of non-liquefiable points with SF greater than 1.

The liquefaction potential (LP) also assessed from MASW dispersion curves is shown as shear wave velocity model in Fig. 6 . It is also observed that the deeper strata are sandy sediments. In respect to the LP, there are three distinctive regions identified on the shear wave velocity model. The low velocity region with shear wave velocities varies from $170-191 \mathrm{~m} / \mathrm{s}$. The intermediate velocity region has velocities which vary from $202-239 \mathrm{~m} / \mathrm{s}$ while the high velocity region has velocities ranging from $235-283 \mathrm{~m} / \mathrm{s}$. The low velocity layer as observed close to the surface and to depth of about $50 \mathrm{~m}$ is made of sandy soils which are liquefiable since the clay prevents the dissipation of pore pressures as well as promoting the formation of sand boils when the underlying sand sediments liquefy. The high velocity region which underlies the sand sediments is identified as clayey soils which are non-liquefiable since the clay prevents the dissipation of pore pressures as well as promoting the formation of sand boils in the sand sediments.

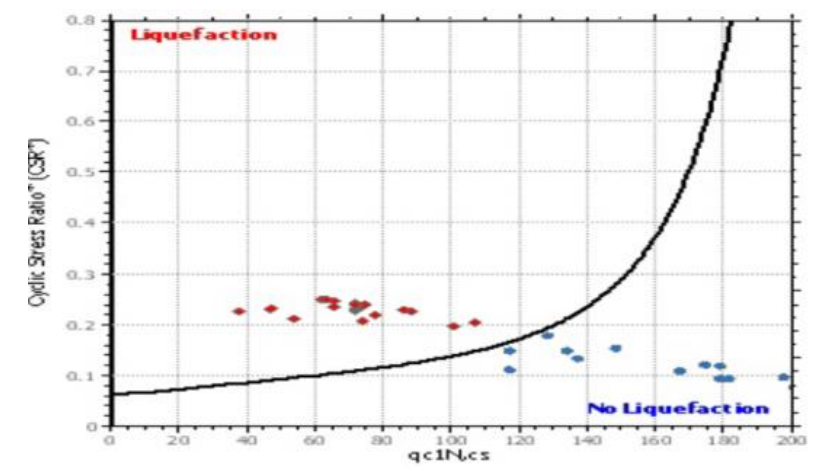

Figure 5: The Liquefaction Model for the study area

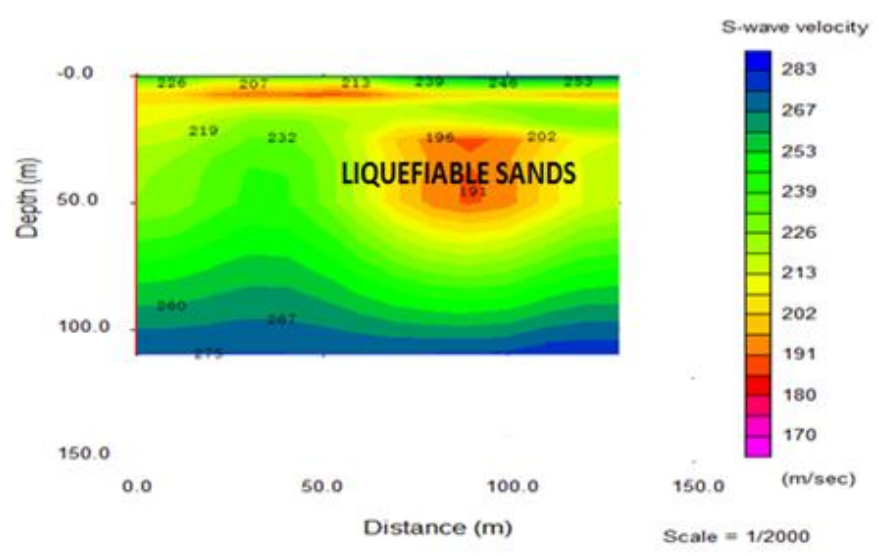

Figure 6: 2-D Shear Wave Velocity Model 


\section{CONCLUSION}

This study presented an assessment of the liquefaction potential of some soils in some parts of the study area. Awareness and early detections towards the recurring of seismic activity occurring inform of earth tremors has been emphasized. The liquefaction potential of the study area using geotechnical and geophysical techniques which depends on the subsoils and the load sitting on the sub-soils has been presented. The distribution of factor of safety in this regard has helped to demarcate the areas that are very susceptible from less prone areas. The 2-D shear wave velocity models delineated saturated loose sands which are prone to liquefaction. This is as a result of low velocity obtained at some points within the depth of liquefaction potential. The simplified procedure on the acquired CPT data shows that the area is at risk of liquefaction due to the dominance of sandy sediments subjected to degree of the cyclic loading involved. The integrated results obtained from the geophysical and geotechnical methods depict high level of conformity. Low Vs obtained shows that the degree of fine content in the sampled area is low. This is because as clay content increases, the cohesion of clay minerals/particles increases its velocity. Likewise, the inter-granular space that exists within suspected liquefiable sands in the study area is low compared to that of clay. The liquefiable sands delineated from the study have shear strength which depends upon the angle of internal friction between the particles. The degree of fines in the sand sediment is not enough to initiate/ cause inter-particular attraction that can hinder the pore water pressure agitation during any increased load.

The physics of liquefaction in soils is particularly related to loading induced tendency of volume strain of the soil skeleton and the resistance to strain. This resistance and the risk of liquefaction are governed by loading characteristics.

Factor of safety against liquefaction deduced from the study is a similitude representation of the concept of inertia. The CSR obtained for liquefiable area are clearly seen to be greater than the CRR of the area. This shows that for liquefaction potential with factor of safety that is less than 1 , the external stress (applied stress) to induce liquefaction must greater than the inbuilt consolidated stress within the soil.

\section{ACKNOWLEDGEMENTS}

The authors would like to thank the anonymous reviewers for their suggestions and comments.

\section{COMPETING INTERESTS}

Authors have declared that no competing interests exist.

\section{AUTHORS' CONTRIBUTIONS}

Hamid Oladunjoye carried out data collection, processing, and prepare the first draft of the manuscript.

Kayode Oyedele conceived of the presented idea and supervised the findings of this work

Lukumon Adeoti supervised the findings of this work and proofread the manuscript

Kehinde Ishola involved in data acquisition, processing and preparation of manuscript

All authors read and approved the final manuscript.

\section{REFERENCES}

1. Marcusson WF. Definition of terms related to Liquefaction. Journal of Geotechnical Engineering Division, ASCE.(1978):104(9):1197-2000

2. Youd TL, Idriss IM, Andrus RD, Arango I, Castro G, Christian JT, Dobry R, Finn WD, Liam, Harder Jr. LF, Hynes ME, Ishihara K, Koester JP, Liao SSC, Marcuson III WF, Martin GR, Mitchell JK, Moriwaki Y, Power MS, Robertson PK, Seed RB, Stokoe KH. Liquefaction Resistance of Soils: Summary Report from the 1996 NCEER and 1998 NCEER/NSF Workshops on Evaluation of Liquefaction Resistance of Soils. Journal of Geotechnical and Geo-environment Engineering, ASCE. 2001:127(4):297-313

3. Salden JA, D'Hollander RD, Krahn JA. The Liquefaction of Sands: a Collapse Surface Approach. Canadian Geotechnical Journal. 1985:22:564-578

4. Dwivedi VK, Dubey RK, Thockholm S, Pancholi V. Assessment of Liquefaction potential of Soil in Ahmedabad Region, Western Indian. Journal of Indian Geophysics Union. 2017:21(2):116-123

5. Pradel D. Procedure to Evaluate EarthquakeInduced Settlements in Dry Sandy Soils. Journal of geotechnical. Engineering ASCE. 1998:101(4):379398.

6. Adepelumi AA, Ako BD, Ajayi TR, Olorunfemi AO, Awoyemi MO, Falebita DE. Integrated geophysical studies of the Ifewara transcurrent fault system, Nigeria. Journal of African Earth Sciences. 2008:52: 161-166

7. Akpan UO, Yakubu TA. A review of Earthquake Occurrences and Observation in Nigeria. Earthquake Sciences 2000:23:289-294. Doi:10.1007/s11589-0100725-7 
8. Anifowose YB, Oladapo MI, Akpan OU, Ologun, CO, Adeoye-Oladapo OO, Tsebeje SY, Yabuku TA. Systematic multi-technique mapping of the southern flank of Iwaraja fault, Nigeria. Journal of Applied Science and Technology. 2010:15(1-2):70-76

9. Mohammed ST, Lar UA, Yakubu TA, Kadiri UA. The Review of the Historical and Recent Seismic Activity in Nigeria. Journal of applied Geology and Geophysics 2015:3(1):48-56

10. Olorunfemi MO, Olarewaju VO, Avci M. Geophysical investigation of a fault zone- Case history from lle-Ife, southwest Nigeria. Geophysical Prospecting. 1986:34(8):1277-1284

11. Samaila NK, Likkason OK. Role of equatorial Fracture zones on Fluid Migration across the South Atlantic Margins. Journal of Earth Science and Climate Change. 2013 Doi: 10.4172/2157-7617-004

12. Seed HB, Tokimatsu K, Harder LF Jr, Chung R. Influence of SPT procedures in soil liquefaction resistance evaluations. Journal of Geotechnical Engineering ASCE. 111:(12):1425-1445

13. Boulanger RW, Wilson DW, Idriss IM. Closure to Examination and reevaluation of SPT-based liquefaction triggering case histories. Journal of Geotechnical and Geo-environmental Engineering, ASCE. 2013:138(8):2000-2001

14. Robertson PK, Wride CE. Cyclic liquefaction and its evaluation based on SPT and CPT. in Proceedings, NCEER Workshop on Evaluation of Liquefaction Resistance of Soils. 1997

15. Robertson PK. Interpretation of cone penetration tests - a unified approach. Canadian Geotechnical Journal. 2013:46:1337-1355.

16. Andrus DA, Stokoe KH. Liquefaction Resistance of Soils from Shear Wave Velocity. Journal of Geotechnical and Geo-enviromental Engineering 2000:126(11):1015-1025

17. Kanyen RE, Moss RE, Cetin KO, Der Kiureghian A, Seed RB. Shear-Wave velocity-based probabilistic and deterministic assesment of seismic soil liquefaction potential. Journal of Geotechnical and Geo-Enviromental Engineering 2013:121:196-212

18. Billman HG. Offshore Stratigraphy and Palaeontology of the Dahomey Embayment, West Africa. Nigerian Association of Petroleum Explorationists Bulletin. 1992:72:121- 130.

19. Jones HA, Hockey RD. The geology of part of South-Western Nigeria. Geological Survey of Nigeria Bulleting. 1964:31.

20. Obaje, NG. Geology and Mineral Resources of Nigeria, Lecture Notes in Earth Sciences. Springer Dordrecht Heidelberg London New York. 1992
21. Omatshola ME, Adegoke OS. Tectonic Evolution and cretaceous stratigraphy of the Dahomey Basin. Nigeria Journal of Mining and Geology. 1981:18(1):130-137.

22. Robertson PK. Soil classification using the cone penetration test. Canadian Geotechnical Journal. 1990:27(1):151-158.

23. Idriss IM, Boulanger RW. SPT-based liquefaction triggering procedures. Report 2010:UCD/CGM-10/02: Department of Civil and Environmental Engineering, University of California, Davis, CA.

24. Seed HB, Idriss IM. Simplified procedure for evaluating soil liquefaction potential. Journal. Soil Mechanics and Foundations Division.1971:1249-273.

25. Olsen RS. Cyclic liquefaction based on the cone penetrometer test. Proceedings of NCEER Workshop on Evaluation of Liquefaction Resistance of Soils, National Center for Earthquake Engineering Research, State University of New York at Buffalo, Report No. NCEER-97-0022, 1997:225-276,

26. Sanchez-Salinero I, Roesset JM, Shao KY, Stokoe II KH, Rix GJ. Analytical evaluation of variables affecting surface wave testing of pavements, Transportation Research Record. 1987:1136:86-95.

27. Burle S, Javeland EH, Enoch S, Guennaeau S, Experiments on Seismic metamaterial: Molding Surface Waves. Physics Review Letter. 2014:112 28. Sheu JC, Stokoe II KH, Roesset JM. Effect of reflected waves in SASW testing of pavements. Transportation Research Record. 1988:1196:51-61. 29. Gucunski N, Woods RD. Instrumentation for SASW testing, in Geotechnical special publication no. 29, Recent advances in instrumentation, data acquisition and testing in soil dynamics, edited by S. K. Bhatia, S. K. and G. W. Blaney, American Society of Civil Engineers, 1988:1-16

30. Xia J. Estimation of near-surface Shear- wave velocities and quality factors using Multi-Channel analysis of surface Wave methods. Journal of applied Geophysics 1988:103:140-151

31. Mcgann CR, Bradley BA, Taylor ML, Wotherspoon, LM, Cubrinovski M. Development of an empirical correlation for predicting shear wave velocity of Christchurch soils from cone penetration tests data. Soil dynamics and Earthquake Engineering, 1988:75:66-75 